of the federal act by the Court of Appeals for the Seventh Circuit denied the protection of the act to a purchaser where the misrepresentations sued on were made neither by means of some interstate method of communication nor by means of the mails, although the transaction came within the purview of the act in other respects. ${ }^{28}$ This defect could be overcome by a provision that civil and penal remedies shall be available for any misrepresentation made by any means and in any connection with a sale of securities by means of interstate communication or of the mails.

But the securities selling industry probably would find exclusive control in the federal government more distasteful than inconsistent state regulation. Furthermore, wide divergence exists as to what exclusive federal regulations should contain. Therefore perhaps the most satisfactory solution that can be hoped for would be the inclusion of provisions in the state acts requiring state administrative agencies to accept for their mechanical requirements copies of documents prepared pursuant to the federal act, and requiring exercise of regulatory powers on the basis of information therein. ${ }^{29}$

It seems likely that the zeal of the state courts for protecting state citizens will cause these courts to follow the lead of the Virginia court in the present case and take full advantage of the wide discretion given them in the International Shoe and Hoopeston decisions. Pending disposition of the present case by the Supreme Court of the United States may settle the matter. ${ }^{30}$ As it stands, in the absence of the suggested federal legislation or of specific exemptions in the state acts, dealers in interstate securities transactions by mail, telephone or telegraph probably will be forced to comply with the Blue-Sky Laws of every state in which they have purchasers. The result will be the exercise by the states of a significant portion of the power delegated to Congress by the Constitution of the United States to regulate commerce among the states..$^{3 x}$

\title{
LIMITATION OF SHIPOWNERS' LIABILITY: SUBSTANCE OR PROCEDURE?
}

According to early maritime codes and the subsequent general maritime law, the liability of a shipowner was limited to his interest in the ship. ${ }^{x}$ But since the nineteenth century decline of the general maritime law, diverse methods of com-

${ }^{28}$ Kemper v. Lohnes, 773 F. $2 d 44$ (C.A. 7 th, 7949 ).

${ }_{29}$ Compare the present Indiana provisions. Ind. Stat. Ann. (Burns, I933) $\$ 25-836$ (cc).

${ }^{3 \circ}$ Probable jurisdiction has been noted and the case transferred to the summary docket. 69 S. Ct. 1496 (1949).

${ }^{3 x}$ U.S. Const. Art. I, § 8.

The Consolato del Mare, probably compiled by private individuals in the Middle Ages by order of the kings of Aragon, "'expressly limits the liability of the part owner to the value of his share in the ship." The Main v. Williams, I52 U.S. I22, I26 (I894). This code eventually "became the common law of all the commercial powers of Europe." 3 Kent Comm. xo; see The Rebecca, 20 Fed. Cas. 373, No. Ir, 619 (D.C. Me., I83r). 
puting the limit have been developed in different countries. ${ }^{2}$ Conflict-of-laws problems have been the result. The solution of these problems may be found in the application of choice-of-law rules which tell the forum whether it should decide a legal problem by its own law or by the law of some other jurisdiction. However, even if the forum is referred to the law of another jurisdiction by its choice-of-law rules, it will not apply that portion of the foreign law which is classified for the purpose of conflict of laws as procedure. Whether limitation of shipowners' liability should be classified as substance or procedure is the problem raised by the recent case of Black Diamond v. Stewart. 3 There an American ship, while proceeding down the Schelde river in the territorial waters of Belgium, collided with a British steamer. The British ship sank with all her cargo and her chief steward was killed. In backing away from the wreck it had caused, the American ship damaged the bank of the Schelde. The United States as owner and the Black Diamond Steamship Corporation as bareboat charterer, upon being pressed with claims of approximately $\$ \mathrm{I}, 000,000$ and anticipating the filing of more claims, brought a petition for a limitation of liability. If the American limitation were to be applied, the petitioners' liability could be no more than $\$ \mathrm{r}, 000,000$, the value of the ship. ${ }^{4}$ The petitioners insisted, however, that their liability was limited by the law of Belgium, inasmuch as the tort occurred in Belgian waters and the general choice-of-law rule is that problems of the law of torts are to be decided according to the law of the place where the alleged tort occurred. Under Belgian law' a shipowner's liability may not exceed the product of eight British pounds sterling multiplied by the tonnage of the ship, which in the case at hand would amount to $\$ 325,000$. The matter at issue in the appeal to the Supreme Court was the amount of the bond to be filed where the applicable substantive liability limit was in doubt. The Court of Appeals for the Second Circuit had thought that the amount of the bond and the applicable liability limit bore no relation to each other. ${ }^{6}$ The Supreme Court, through Jus-

In addition to the growth of divergencies as to the kind of damage for which the shipowner's liability wauld be limited, the English and Uniform Convention systems, both widely copied, base the liability limitation upon the product of a constant sum of money multiplied by the tonnage of the ship. For detailed studie's of the different systems see 3 Benedict on Admiralty $\$ 543$ ( 1940 ); Kuhn, International Aspects of the Titanic Case, 9 Am. J. Int. L. 336 (I9r5); Sprague, Iimitation of Ship Owners' Liability, I2 N.Y.U.L.Q. Rev. 568 (I935); Maritime Law Association, Report on History and Present Status of Domestic and Foreign Laws Concerning Limitation of Shipowner's Liability (I935); see also The Main v. Williams, I52 U.S. 122 (1894).

${ }^{3} 336$ U.S. 386 (I949).

4 R.S. $\& 4285$, as amended 49 Stat. 1480 (1936), 46 U.S.C.A. \& 885 (Supp. I949).

5 Belgium has ratified the International Convention for the Unification of Certain Rules relating to the Limitation of the Liability of Owners of Seagoing Vessels, signed at Brussels on August 25, 1924.

6 The court of appeals found that the petitioners had "impaled themselves on the horns of a dilemma." The dilemma arose in the following manner: The statute provides that "[ $t]$ he vessel owner, within six months after a claimant shall have given to or filed with such owner 
tice Frankfurter, reversed the decision, remanded the case, and instructed that "the question of what law governs the substantive limit of liability should be determined upon remand in advance of the proof of individual claims." He left to the lower court the determination of the proper law governing the substantive limit, saying that "if it is the law of Belgium that the wrong creates no greater liability than that recognized by the Convention of $\mathrm{x} 924$, we cannot, without more, regard our own statutes as expanding the right to recover. ... If, on the other hand, the Convention merely provides procedural machinery by which claims otherwise created are brought into concourse and scaled down to their proportionate share of a limited fund, we would respect the equally well settled principle that the forum is not governed by foreign rules of procedure. We leave open the choice between these opposing hypotheses. Nor do we mean to imply that these apparently clear-cut alternatives are exhaustive."

It would appear that Justice Frankfurter has misstated the "well settled principle" of the conflict of laws concerning substance and procedure, for these terms as used in the conflict of laws are exhaustive alternatives. Had the correct

written notice of claim, may petition a district court of the United States of competent jurisdiction for limitation of liability within the provisions of this chapter, as amended, and the owner (a) shall deposit with the court, for the benefit of claimants, a sum equal to the amount or value of the interest of such owner in the vessel and freight, or approved security therefore $\ldots$ or (b) at his option shall transfer, for the benefit of claimants, to a trustee to be appointed by the court his interest in the vessel and freight. ..." Petitioners had argued that their liability should be limited to $\$ 325,000$ by application of the Belgian statute. They concluded that although their ship was worth $\$ 1,000,000$ they should only be required to put up a bond of $\$ 325,000$. Otherwise, they reasoned, the only result which would follow from any bond over $\$ 325,000$ would be excess profit for the bonding companies. The Circuit Court relied upon three decisions: The Aquitania, 20 F. 2d 457 (C.C.A. 2d, r927); Curtis Bay Towing Co. v. Tug Kevin Moran, 159 F. 2d 273 (C.C.A. 2d, I947); The George W. Fields, 237 Fed. 403 (D.C. N.Y., r915). These three decisions held that where aggregate claims against a shipowner can by no possibility exceed the value of the ship, a proceeding under R.S. $\$ 4285$ would not lie. The Circuit Court thought that the petitioners had impaled themselves upon the horns of a dilemma because, "[i]f in fact the limit of all their liabilities is $\$ 325,000$ and their ship is worth $\$ \mathrm{I}, \infty 00, \infty 00$, they have no right to commence such a proceeding as this at all, and are confined to asserting their privilege as a defense to any suits which may be brought against them.... If on the other hand they are wrong and the liabilities may go beyond $\$ 325,000$, on their own argument the bond they propose is too small." United States v. Stewart, ${ }^{6} 67$ F. $2 \mathrm{~d} 308,309$ (C.C.A. 2 d, I948).

Justice Frankfurter was able to resolve the dilemma by reasoning that "a sum equal to the amount or value of the interest of such owner in the vessel or freight," as used in R.S. $\S 4285$, means the substantive limit of the owner's liability. However, even though under Justice Frankfurter's interpretation of the statute the petitioners could file the smaller bond if their substantive limit of liability were below the value of their interest in the ship and freight, in the case at hand the applicable substantive limit was the issue in question. Justice Frankfurter therefore required the Black Diamond Steamship Corporation to post a bond for the value of the ship and freight, "not because $\$ 4285$ demands it, but as an exercise of its power to preserve the stahus quo pending appeal." Black Diamond v. Stewart, 336 U.S. 386, 399 ( 1949 ). Justice Jackson, dissenting, pointed out that "[o]ur statute is clear: $\$ 4283$ fixes the maximum liability at ship plus freight and $\$ 4285$ sets the minimum security at the same figure. To provide any other limit of liability or security is to rewrite both sections." Ibid., at 400 .

7 Black Diamond v. Stewart, 336 U.S. 386, 396 (x949). 
test for classifying foreign legal rules been applied, the problem of determining the amount to which the liability of a shipowner may be limited would be classified as one of substantive law. This result is supported by an analysis of the theory of choice-of-law rules as accepted by leading modern authorities. ${ }^{8}$

Conflict-of-laws doctrines are based essentially on the concept of justice. Laws are said to be just by a particular society if they correspond to the moral and social value judgments which are held by that society. In almost every society one of the most important of these value judgments is that men's reasonable expectations ought to be fulfilled. Where the law differs from one jurisdiction to another three special types of expectation reasonably arise. First, since people often engage in transactions which have contacts with more than one jurisdiction, they reasonably expect that legal controversies which contain significant contacts with foreign jurisdictions will be adjudicated by the forum. In the second place, people expect that the obligations arising from any event will be adjudicated in a uniform way, no matter where the case may happen to be litigated. Finally, people frame their expectations with reference to the legal system with which their legal relationships have the most significant contacts at the time of the event in question, and expect that the law of that jurisdiction will govern those relationships.

Conflict-of-laws rules are an attempt to fulfill these expectations. The first type was met by the development of modern jurisdictional rules. The last two can be fulfilled only when courts will occasionally decide cases by the law of another jurisdiction. Choice-of-law rules lead to this result, for they tell the forum to what law it should look to decide a particular legal problem. These rules are applied by the court only after it has "characterized" the various legal problems in a case, for choice-of-law rules are formulated in terms of particular legal problems. For example, to determine whether a defendant is liable for negligently striking and injuring the plaintiff, a court would first classify the question as a problem of the law of torts. To determine what law to apply to the case, the court would then look to the choice-of-law rule for problems of the law of torts and would find that such problems are decided according to the law of the place where the alleged tort occurred. After the proper law has been selected for each legal problem of the case, the court must then decide the extent to which this law is applicable. In the vast majority of cases, all the significant contacts are with the forum, and the court does not hesitate to apply the local law in its entirety. For if it is just that the forum's law should apply to a legal problem, it is just that the entire law of the forum should be used so that particular rules will not be applied out of their context within the system. Likewise, if the parties' justified expectations are dependent upon foreign law, that law, except for choice-of-law rules, should be applied in its entirety. This enables the forum

8 The analysis developed here is a synthesis of the views presented in the following works: Hancock, Torts in the Conflict of Laws c. iv (I942); Rabel, The Conflict of Laws: A Comparative Study vol. II, c. 27 (1947). See also Stumberg, Principles of Conflict of Laws I48 (r947); Cook, "Substance" and "Procedure" in the Conflict of Laws, 42 Yale L.J. 333 (r933). 
to achieve the same result as would have been reached had the case been litigated in the foreign jurisdiction.9

Three limitations, often confused in practice, may be placed upon this otherwise sweeping reference. First, a statute of the forum may have displaced the otherwise applicable choice-of-law rules by declaring that regardless of the significant contacts of the case the law of the forum is to be applied. Second, where the forum does not wish to decide a case in a fashion entirely contrary to local notions of justice, it may refuse to enforce the foreign law on grounds that it would violate the public policy of the forum. This public policy may be found embodied in a statute, in the case law of the jurisdiction, or merely in the judges' interpretations of community sentiment. The third limitation arises insofar as application of the foreign law would involve taking steps for which the forum's courts are not organized or equipped. For example, if referred to French law an American court would not be able to carry on the trial in the French language as is required by French law and would properly refuse to enforce that rule. When the forum refuses to apply a foreign rule of law on this ground, it classifies that rule as procedural and applies the corresponding rule of its own. Otherwise, the foreign rule of law is classified as substantive and is applied by the forum. It is obvious, therefore, that as used in the conflict of laws the words substance and procedure are exhaustive alternatives.

Taken in its context in the Black Diamond case, Justice Frankfurter's statement that "the forum is not governed by foreign rules of procedure," indicates that he thinks the proper test for classification of a foreign legal rule as substantive or procedural lies in an analysis of the function of the rule in the foreign legal system. However, no matter what the significance of the shipowner's liability limit in the Belgian legal system, had the case been litigated in Belgium the Belgian courts would have applied their own limitation, unless, of course, under their choice-of-law rules, they would have been referred to some other legal system. Likewise, it would be illogical for the forum to refer to foreign law in order to achieve uniformity of decision and thereby to fulfill justified expectations of the parties to the dispute, and then refuse to apply a particular rule of the forum law merely because the foreign jurisdiction for some reason entirely unconnected with the case at hand classified its rule as procedural. It would be equally illogical to classify a foreign rule as procedural merely because the forum had previously labeled the type of rule as procedural for some purpose unconnected with the conflict of laws.

It is important to note that when a court classifies a foreign rule as procedural, it is refusing to step completely into the shoes of the foreign courts.

- This is not to forget, of course, that a single case may have more than one legal problem in it, and that consequently the forum may be referred to more than one foreign law. See Buckeye v. Buckeye, 203 Wis. 248,234 N.W. 342 (1931), where the court failed to see this problem. The case was criticized in 3 I Col. I. Rev. 884 (I93I); 44 Harv. L. Rev. II38 (I93I); 29 Mich. L. Rev. I072 (193I); 79 U. of Pa. L. Rev. 804 (I93I); 6 Wis. L. Rev. I03 (I93I).

so 336 U.S. 386,396 (I949). 
This refusal cannot be supported by any notions of justice relevant to the particular case at hand, because, by hypothesis, the court has looked to the foreign law in order that the case might be decided in accordance with its "proper" law. Thus, the forum ought to restrict the classification of problems as procedural as much as is compatible with the effective administration of justice.

Turning to the problem of determining to what extent the limitation of a shipowner's liability is a matter of substance or procedure, it follows that the rule stating the maximum amount of liability should be classified as substantive to the extent that the application of a foreign liability limit would not interfere in any way with the smooth running of the American judicial machinery. It is true that in every legal system the limitation of liability is part of a complicated legislative scheme. But this should not be cause for hesitation since the distinction between the substantive and procedural rules within the statutes is quite simple. The actual monetary limitation may easily be abstracted from all the provisions which would interfere with those rules of the forum that indicate by what steps the shipowner may obtain a liability limit. Thus the notices to be sent and the various papers to be made out are part of the forum's machinery which has been set up to handle this specific situation. Deviation from these rules might indeed be inconvenient. Application of the actual monetary limit itself, however, presents no such difficulties.

An analysis of the results of classifying the determination of the amount of a shipowner's liability limit as procedural fortifies the above answer. If procedural, then the jurisdiction with the highest limit becomes a haven for claimants, while the jurisdiction with the lowest limit will become desirable to shipowners. The owner of a ship which has caused some damage races for a lowliability port. The claimant tries to catch the shipowner in a high-liability port. Uniformity in this situation is impossible and the mere existence of such a race should not be countenanced by any rational legal system. On the other hand, if the limitation is substantive the rights and duties are fixed as of the moment of the occurrence of the controversial event. This result is in accord with the majority of continental European courts, which do not hesitate to apply the foreign limitation of liability as a matter of substance. ${ }^{x x}$

If the foregoing analysis is correct, The Titanic ${ }^{12}$ should be re-examined. The British ship Titanic on her maiden voyage from England struck an iceberg on the high seas and sank. The owners petitioned for a limitation of liability in an American court. The case of The Scotland ${ }^{\mathrm{r} 3}$ previously had decided that foreign shipowners could obtain a limitation of liability in American courts, and had indicated by dicta that the law of the flag would govern the existence of the owner's liability where the accident was on the high seas. Thus the question for decision in The Titanic was whether British law applied to the limitation of liability as well as to the existence of liability, or whether the American limita-

Ix Rabel, op. cit. supra note 8 , at 353 .

12233 U.S. 718 (Igr4).

${ }^{23}$ I05 U.S. 24 (I88I). 
tion of liability would govern irrespective of the law to which choice-of-law rules would otherwise refer. Since the American statute has left the scope of its application unformulated, the Supreme Court had to resort to general principles. Justice McKenna thought that The Scotland authorized application of the British limitation of liability. Although Justice Holmes, for the majority, reasoned that under the The Scotland the American statute should be applied, his conclusion appears questionable. In The Scotland Justice Bradley had addressed himself to different problems-whether British or American law governed the existence of liability and whether a foreign shipowner could avail himself of the American limitation of liability machinery.

So the problem remains: Upon what ground did The Titanic refuse to apply the British limitation of liability, which by general choice-of-law rules would have been applied? As previously stated, there are only three types of limitations upon an otherwise applicable reference to foreign law. Therefore, The Titanic must have held either that the American statute required that American law be applied regardless of the otherwise applicable choice-of-law rule; or that the application of the foreign limitation would be contrary to the public policy embodied in the statute; or finally, that limitation of liability must be classified as procedure.

The choice is not readily apparent. A study of The Titanic opinion and of a similar case, Emery v. Burbank, ${ }^{\text {, }}$ decided nineteen years earlier when Holmes was a judge of the Massachusetts Supreme Court, leads to the conclusion that he did not have the distinctions clearly in mind. In both cases, faced with a statute of undetermined scope, Holmes resolved the ambiguity in favor of broad application without articulating an analytical argument. The Titanic may perhaps best be explained by noting that Holmes failed to make any distinction between the provisions of the limitation statutes which outline the steps to be taken by a shipowner in obtaining a liability limit, and the substantive limit itself. Faced with the choice of applying the British statute in its entirety or the American statute, he would be naturally inclined to favor the American statute; for American judicial machinery was not organized to take all the various steps required by the British statute.

The Black Diamond case gives the Supreme Court the opportunity to choose -in a sense has already forced the choice-between the three types of limitations. The Court appears to have rejected the view that the American statute substitutes its provisions for the otherwise applicable choice-of-law rules, by stating in the Black Diamond opinion that "if, indeed, the Belgian limitation attaches to the right, then nothing in The Titanic stands in the way of observing that limitation." Is By remanding the case and instructing the lower court to determine whether the Belgian limitation of liability is a matter of substance or procedure, the Supreme Court has implicitly denied that The Titanic decided that problem, and the Court has become implicitly aligned with the authorities holding that The Titanic was a "public policy" decision. Yet it is difficult to con-

${ }^{14}{ }_{163}$ Mass. 326, 39 N.E. 1026 (I895).

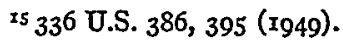


ceive that the American statute purports to declare that the enforcement of a foreign limitation of liability would be offensive to our notions of justice, while at the same time enacting a limitation of liability substantially like those of foreign countries. If, on the other hand, the distinction is made between the substantive limit of liability and the steps whereby this limit may be obtained by a shipowner, the applicable policy arguments relevant to the conflict of laws all are in favor of the restricted scope of the statute. If these policy arguments and the correct conflict-of-laws theory were followed, the American courts would apply the monetary limit of the American statute only when referred to that statute by choice-of-law rules. But as matters now stand, insofar as The Titanic limits the applicability of foreign limitation of liability statutes, it operates as a last remnant of the idea that each nation should mete out the law of nations as it interprets that law. This notion has long been repudiated and has been superseded by the conflict of laws, a legal technique based upon a more realistic appraisal of world conditions. ${ }^{26}$

\section{LEGAL STATUS OF INFANT EN VENTRE SA MÈRE}

Traditionally the question of whether an infant can sue for injuries sustained while en ventre sa mère ${ }^{x}$ through the negligence of others has been answered in the negative. ${ }^{2}$ The principal reasons given for denying recovery have been: ${ }^{3}$

${ }^{6} \mathrm{~A}$ recent article in the Columbia Law Review agrees that The Titanic should be reexamined. Knauth, Renvoi and Other Conflicts Problems in Transportation Law, 49 Col. L. Rev. I (I949). Concerning the Black Diamond case, the author notes that three different suits are being brought against the owners. The British shipowners are suing in England, the cargo owners are suing in the United States, and a wreck removal suit will be brought in Belgium. He points out that if the United States and Great Britain both declare the limitation of liability to be a matter of procedure, "the parties plaintiff, by artfully dividing their lawsuits between these very three States (each of which has a statute limiting a shipowner's liability) will actually circumvent the common policy declared by all three States, and may succeed in recovering judgments aggregating over $\$ 2,000,000$ - or seven times the Belgian limitation statute figure -and will presumably collect on those judgments." In Mr. Knauth's opinion The Titanic will contribute to this result, although, "[t]he Court's ruling on the limitation point has always been a matter of some doubt, and it may now be re-examined in the Merganser-Norwalk Victory litigation [the Black Diamond case]."

$x$ The term "en ventre sa mère" refers to a child still within the mother's womb.

${ }^{2}$ Dietrich v. Inhabitants of Northhampton, I38 Mass. 44 (1884); Stemmer v. Kline, I28 N.J.I. 455, 26 A. $2 \mathrm{~d} 489$ (I942); Ryan v. Public Service Coordinated Transport, I8 N.J. Misc. 429, 14 A. 2d 52 (r940); Berlin v. J. C. Penney Co., 339 Pa. 547, I6 A. 2d 28 (1940); Smith v. Luckhardt, 299 Iil. App. 100, I9 N.E. 2d 446 (1939); Newman v. Detroit, 28I Mich. 60, 274 N.W. 7ro (I937); Magnolia Coca Cola Bottling Co. v. Jordan, x 24 Tex. 347, 78 S.W. 2d 944 (1935); Stanford v. St. Louis \& San Francisco Ry. Co., 214 Ala. 6r I, 108 So. 566 (1926); Drobner v. Peters, 232 N.Y. 220, 133 N.E. 567 (1921); Lipps v. Milwaukee Electric Ry. \& Light Co., 164 Wis. 272, I59 N.W. 916 (I916); Nugent v. Brooklyn Heights Ry. Co., I54 App. Div. 667,139 N.Y. Supp. 367 (19r3); Walker v. Great Northern Ry. Co. of Ireland, 28 I. R. Fr. 69 (I891). Contra: Bonbrest v. Kotz, 65 F. Supp. r38 (D.C. I946); Scott v. McPheeters, 33 Cal. App. $2 \mathrm{~d} 629,92$ P. $2 \mathrm{~d} 678$ (r939) (on the basis of a California statute); Montreal Tramways v. Leveille, [r933] 4 Dom. L.R. 337; Cooper v. Blanck, 39 So. $2 \mathrm{~d} 352$ (La. App., r923) (published in 1949). See also notes 12 and 13 , infra.

3 See Judge Pound's opinion in Drobner v. Peters, 232 N.Y. 220 . I33 N.E. 567 (r92I), in which he lists as reasons for denying recovery: I) lack of authority, 2) practical inconvenience 